\title{
Integrated Pharmacy Research and Practice
}

This article was published in the following Dove Press journal:

Integrated Pharmacy Research and Practice

28 June 2012

Number of times this article has been viewed

\section{Adam Todd' \\ Jonathan Ling ${ }^{2}$}

'Wolfson Research Institute, School of Medicine and Health, Queen's Campus, Durham University, Stockton-on-Tees, UK; ${ }^{2}$ Faculty of Applied Sciences, University of Sunderland, Sunderland, UK
Correspondence: Adam Todd

Wolfson Research Institute, School of Medicine and Health, Queen's Campus, Durham University, Stockton-on-Tees TSI7 6BH, UK

Email adam.todd@durham.ac.uk
By 2014, the worldwide annual spend on medicines is expected to exceed one trillion dollars, representing an increase of nearly $90 \%$ since $2005 .{ }^{1}$ Thanks to modern medicine and the expanding number of pharmaceutical agents used to treat a wide range of diseases, average life expectancy is also set to increase, with, for example, average life expectancy in the UK increasing to 80 years of age, which is eight years higher than in the 1970s. ${ }^{2}$ However, despite this success, people around the world fail to use their medicines as they should, with a recent report by the World Health Organization estimating that, in developed countries, around $50 \%$ of patients are noncompliant with their long-term medication. ${ }^{3}$ In developing countries, this percentage is even higher, which is of particular concern because infectious diseases, such as human immunodeficiency virus and tuberculosis, are spreading rapidly. In view of this, the concept of "pharmaceutical care" has been introduced, and is defined as "the responsible provision of drug therapy for the purpose of achieving definite outcomes that improve (or maintain) a patient's quality of life". 4

The famous observation by C Everett Koop, the former US Surgeon General, that "Drugs don't work in patients who don't take them" has never been as important as it is now ${ }^{5}$ and, considering the vast sums of money spent on medicines, research into using them more effectively is a key priority, especially given the current world financial climate. Pharmacy practice, that is, helping people use their medicines more effectively and safely, is seen by many as a key means of achieving this. Indeed, studies have shown that pharmacy interventions can help patients use their medicines more effectively, or even prevent patients from coming to harm, by identifying inappropriate, or in some cases dangerous, prescribing practices. Indeed, one recent study ${ }^{6}$ has shown that hospital pharmacists carry out an average of 0.019 medicine interventions per patient day, some of which identified errors that were potentially fatal, and could be considered a significant number given the large amount of patients admitted to hospital worldwide.

While studies have shown pharmacy practice can have a major impact on the pharmaceutical care of patients, the current evidence base still needs strengthening. Therefore, we are interested in receiving articles that build upon and consolidate understanding of the effectiveness and role of pharmacy practice, both in terms of quality, safety, patient experience, outcome, and cost.

To disseminate information quickly and facilitate the exchange of ideas related to pharmacy practice research, Dove Medical Press has launched a new journal entitled submit your manuscript | www.dovepress.com

Dovepress

http://dx.doi.org/1 0.2147/IPRP.S30272
Integrated Pharmacy Research and Practice 20 I2:I I-2

(C) 2012 Todd and Ling, publisher and licensee Dove Medical Press Ltd. This is an Open Access article which permits unrestricted noncommercial use, provided the original work is properly cited. 
Integrated Pharmacy Research and Practice. In the first issue of the journal, we invite authors to submit articles on all aspects of pharmacy practice research, whether in community, hospital, or industry. We would particularly welcome submissions that integrate areas of pharmacy practice. As an international and open access journal, your article will be available to a broad audience all over the world.

The journal serves as a practical and compelling platform to disseminate and share your research findings or clinical observations quickly, and we are certain that you will find Integrated Pharmacy Research and Practice a valuable resource. The journal welcomes submission of original research, commentary, reviews, editorials, and expert opinion. We will also consider case reports or case series that provide new insight into pharmacy practice research. Our editorial board includes experts from all aspects of pharmacy, and we are confident that you will find our turnaround time rapid and our peer reviewers' comments useful and constructive. Integrated Pharmacy Research and Practice will be submitted to PubMed Central as soon as it has met the necessary criteria. All of our older journals are indexed on PubMed Central, so we expect Integrated Pharmacy Research and Practice to be accepted once the application has been submitted.

\section{Disclosure}

The authors report no conflicts of interest in this work.

\section{References}

1. IMS Institute for Healthcare Informatics. The global use of medicines. Outlook through 2015. Available from: http:/www.imshealth.com/ deployedfiles/ims/Global/Content/Insights/IMS\%20Institute\%20for $\% 20$ Healthcare\%20Informatics/Global_Use_of_Medicines_Report.pdf. Accessed April 23, 2012.

2. Leon DA. Trends in European life expectancy: a salutary view. Int $J$ Epidemiol. 2011;40:271-277.

3. World Health Organization. Adherence to long-term therapies: Evidence for action, 2003. Available from: http://whqlibdoc.who.int/ publications/2003/9241545992.pdf. Accessed April 23, 2012.

4. World Health Organization. Developing pharmacy practice: A focus on patient care, 2006. Available from: http://www.fip.org/files/fip/publications/ DevelopingPharmacyPractice/DevelopingPharmacyPracticeEN.pdf. Accessed April 23, 2012.

5. Osterberg L, Blaschke T. Adherence to medication. N Engl J Med. 2005; 353:487-497.

6. Fernández-Llamazares CM, Calleja-Hernandez MA, ManriqueRodriguez S, Pérez-Sanz C, Duran-García E, Sanjurjo-Saez M. Impact of clinical pharmacist interventions in reducing paediatric prescribing errors. Arch Dis Child. February 22, 2012. [Epub ahead of print.]
Integrated Pharmacy Research and Practice

\section{Publish your work in this journal}

Integrated Pharmacy Research and Practice is an international, peer-reviewed, open access, online journal, publishing original research, reports, reviews and commentaries on all areas of academic and professional pharmacy practice. This journal aims to represent the academic output of pharmacists and pharmacy practice with particular focus on integrated care. All papers are carefully peer reviewed

\section{Dovepress}

to ensure the highest standards as well as ensuring that we are informing and stimulating pharmaceutical professionals. The manuscript management system is completely online and includes a very quick and fair peer-review system, which is all easy to use. Visit http://www.dovepress.com/testimonials.php to read real quotes from published authors. 